\title{
SAFETY OF SPORTS MASS EVENTS IN THE CONTEXT OF CREATING A MARKETING PRODUCT
}

doi: $\quad 10.2478 /$ czoto-2019-0109

Date of submission of the article to the Editor: 03/12/2018

Date of acceptance of the article by the Editor: 16/01/2019

\author{
Izabella Sowier-Kasprzyk ${ }^{1}$ - orcid id: 0000-0001-8458-2295 \\ Sławomir Kowalski ${ }^{2}$ - orcid id: 0000-0002-5421-5053 \\ ${ }^{1}$ Częstochowa University of Technology Poland, izabella.sowier-kasprzyk@wz.pcz.pl \\ ${ }^{2}$ Częstochowa University of Technology Poland, slawomir.kowalski@wz.pcz.pl
}

\begin{abstract}
Safety as a state that gives a sense of confidence and a guarantee of its maintaining may also act as an element motivating to use a product or service, certainty of use of the product and the certainty of using the service. In the second approach, mass-specific services, including sports services related to the operation of sports clubs, are a service specific in terms of security. The entity providing them should ensure the safety of all its participants, from sportsmen to sports spectators. The aim of the article is to present partial results of research results on the relationship between the sense of safety of sports club fans and active participation in a sports event. The research covered a group of 1127 people surveyed in the first half of 2018 using a direct questionnaire on fans of sports teams and research on secondary sources.

The main hypothesis is that a sporting event allows to extend a marketing offer to new segments, enrich the expanded sports product, set new pricing strategies and use promotion only when a viewer has a high sense of security. In this approach, it is security from the point of view of the customer that determines the use of a sports service, but also satisfaction, and, in the future, also loyalty.
\end{abstract}

Keywords: safety of mass events, marketing, sport marketing

\section{INTRODUCTION}

Sports events belong to the category of mass events. The risk associated with their organization is connected primarily with the presence of a large group of people in a closed facility, and emotions associated with the event. Any deviation from the established rules and the normal course of the event amplifies the danger of panic and other threats to health and life.

Potential hazards include those that might be caused by technical failures, hazards caused by a human intentionally or unintentionally, and natural reasons. Among technical incidents typical technical failures should be mentioned, for example, a power supply interruption or interference in a communication system. The second group of adverse events includes intentional human activity, which simultaneously 
carries a potential threat to the safety of participants of mass events. These incidents may be caused by organized criminal or terrorist groups or individuals unrelated to any of the organizations listed. The last group of incidents comprise of incidents caused by the forces of nature, and, thus, independent of human will, and difficult to predict in terms of the scale of possible impact on the security of a mass event of a special significance. Usually, they are considered possible, but with a small degree of probability (Łukawski, 2016, Kaviya et al., 2010).

The basis for the discussion on the safety of mass events (including sports events) is the reference to the existing law. The rules for their organization were laid down in the Act of March 20, 2009 on the safety of mass events. This law defines a mass event as an artistic or entertainment event to be held:

a) in a stadium, in another facility that is not a building or in an area that enables a mass event, where the number of places is available to the public, determined in accordance with the provisions of the Construction Law and fire protection regulations, and is not less than 1000,

b) in a sports hall or other building that enables a mass event in which the number of places for persons provided by the organizer, determined in accordance with the provisions of the Construction Law and fire protection regulations, is not less than 500 (Article 3. of the Act of 20 March 2009 on the safety of mass events, Journal of Laws, No. 62 2009, item 504).

Security of the mass spectacle "consists in meeting its security requirements by persons participating in the event, protecting public order, providing medical security and ensuring proper technical condition of buildings together with the technical installations and devices, including fire and sanitary facilities serving them (Suski, 2010, Borys at al., 2012). "

An extremely important element characterizing mass events is the type of the event, the place of the event, the planned number of participants who intend to take part in the event and the degree of risk accompanying the event. Depending on whether the event takes place at the stadium or the hall, a different number of people are considered as minimal to consider it as mass, and the organizer's specific activities depend on it (Szymonik, 2011).

It should also be noted that mass events excluded from the law on the safety of mass events are events organized in places such as:

a) theatres, operas, operettas, concert halls, cinemas, museums, libraries, cultural centres and art galleries or other similar facilities,

b) in schools and educational institutions by the management of these schools and institutions,

c) as part of sports competitions for children and adolescents,

d) in the case of disabled athletes,

e) sport for all as a physical recreation, freely and selflessly, organized in an open area,

f) closed organized by employers for their employees (Jędrzejas, 2017).

The organizer's obligations arise from the above-mentioned Act. The process of ensuring safety should take into account the expected capacity of the stadium sectors in relation to the controlled flow of people when entering or leaving the space of the event. All activities should also be aimed at providing the protection of target groups (fans, journalists, sponsors, people from the VIP sectors), as well as focus on viewers' observation and reacting to events. Ongoing risk management within the framework 
of the collateral is to enable maintaining public order and preventing crimes and detecting them as well as counteracting threats related to terrorism.

Ensuring security during a mass event on the organizer's side includes:

- meeting the requirements expressed in the provisions of construction law, sanitary regulations and fire protection;

- ensuring the participation of information and security services and the safety manager; - providing medical assistance;

- providing hygienic and sanitary facilities;

- designation of escape routes;

- providing communication;

- provision of appropriate rescue and firefighting equipment;

- designation of a place for services managing security (Parszowski and Kryczyński, 2015).

Security at a mass event is also associated with predicting specific crowd behaviours and ensuring its dynamic flow before, during and after the event.

To this end, the following elements related to the security of events are characterized:

1. Routes, where it determines the directions people reach to get to the event, navigate the site and leave it (flow path analysis).

2. Areas where the potential of each event sector is determined and the location of crowd density (low, medium and high) and the risk related to the location of these locations.

3. Traffic, where it measures the speed of passage through various parts of the system (for example speed of service when entering the stadium, checking tickets and controls) and the general flow of the crowd (flow rate analysis) in place.

4. Profile, where expected crowd behaviour is estimated when moving between sites (Raineri, 2016).

While the organizer must provide specialized protection during the organization of the event, the largest range of security rules for mass events in Poland remains with the Police (Wojciechowski, 2013). All the activities of services supporting the security of mass events must be well coordinated. The aspect of information flow and cooperation between all services is very important. It should be remembered that every service is responsible for a certain area of logistic activities that must be professionally organized (Kulińska, 2014).

Many police activities are carried out in advance. According to Article 22 section 4 of the Act on Safety of Mass Events. The Police may restore order to stadium facilities or on the premises delineated and qualified for the mass event. Each of its activities is undertaken at the request of the organizer or safety manager (Popławski, 2016). This is very important especially for sports events.

All the time it is need to keep in mind that the entity organizing the mass event is responsible for the safety of its participants in the place and time of the event (Kamiński and Majchrzak, 2012, Lee and Fereira, 2012).

\section{METHODOLOGY OF RESEARCH}

All the above obligations result not only from the law, but also affect the sense of security of participants of mass events (including sports). Owing to this feeling of safety, a sports club can create an extended product which is its effect based on segments for which this safety is particularly important. 
This is important because there are disciplines that trigger special emotions, and the most die-hard supporters are people whose attitude does not affect the sense of security of other spectators.

The study underlying the article was carried out in several stages in March, April and May 2018. It concerned the reception of the phenomenon of supporting and the role of sports club in creating positive behaviour in a stadium. In this way, with the help of a questionnaire consisted originally from 34 questions, there was a broad understanding impact of marketing tools on the club's activities. Due to the specificity of the sports discipline, the focus was exclusively on fans of football clubs of different classes.

In the first stage, about two hundred people from the Czestochowa region were subjected to research, then it was extended to the Silesian Voivodeship, mainly people from Chorzow, Katowice and Zabrze. In order to be able to compare results from subsequent stages with one other, the questions specific to regions were excluded, and a questionnaire with 30 questions was created.

The selection of the sample was an accidental choice, where the criterion of selection was the fact of being a fan of any football clubs, regardless of presence at matches or not. In the course of the research proceedings, a total of 1,127 questionnaires were collected in direct and online contact. Although not all the questions were fully completed, they were all included in the analysis.

The study also included issues related to the safety of participants and a sense of threat. Questions concerning security, the role of the police, the work of security services and information services are the basis for the article. On their basis, a hypothesis was established that safety is the basic value that determines the participation in a football match at club level. Therefore, in addition to activities aimed at complying with the law, active prevention of threats and raising the sense of security with the use of available marketing instruments is important.

As a result of the research, it was found that nearly half of the respondents feel safe at the sports facility (Figure 1).

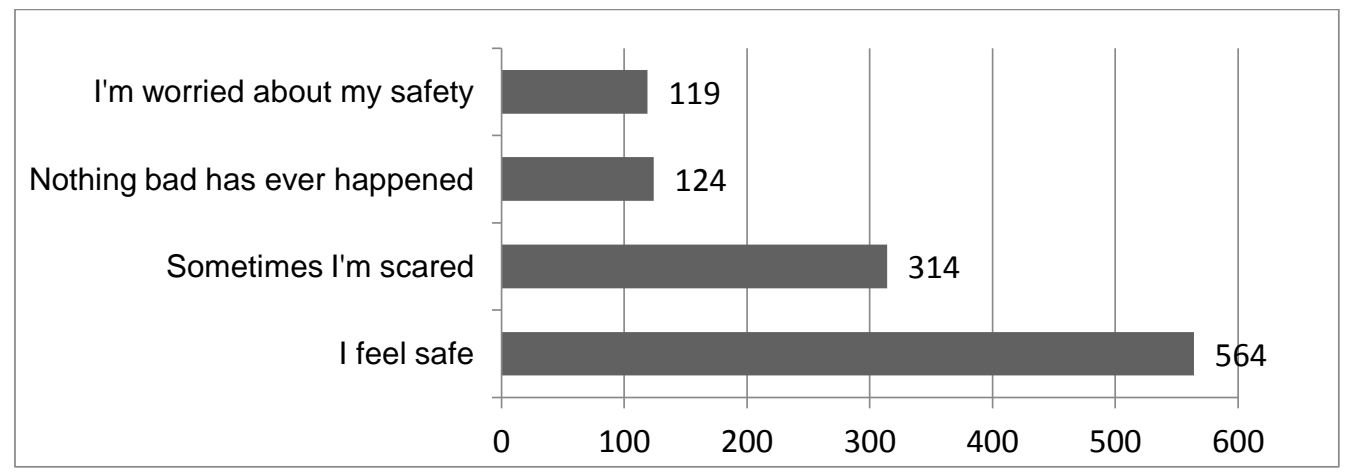

Fig. 1. Sense of the safety of the fans in the stadium

As it can be seen in Figure 1., although the majority is not afraid of any threat, about ten percent of respondents, who do not feel comfortable, fear for their safety. This threat may result from the lack of trust in the services and the police as well as concerns the behaviour of others. Concern is also evidenced by the answer to the question about the evaluation of police work at football matches. 


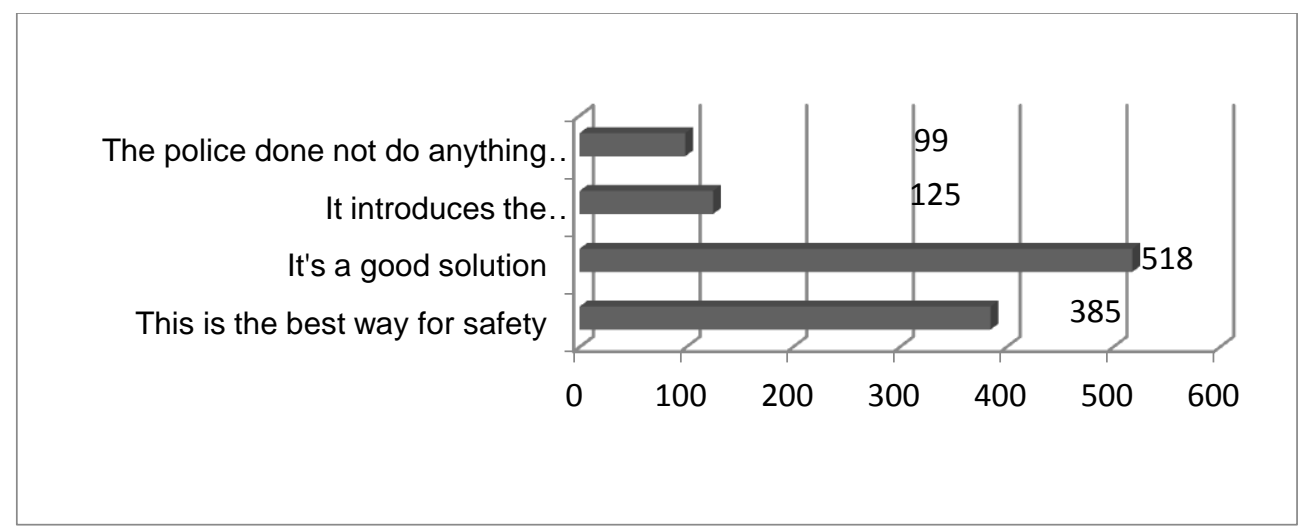

Fig. 2. Evaluation of the police presence at matches

Most respondents believe that the police perform their preventive tasks well, which makes the fans feel safe. There is still a group of about $20 \%$ of respondents dissatisfied with the work of the police. At the same time, it should be noted that the respondents who also attend the club matches occasionally gave answers.

The basic research in this article concerned the impact of a sense of security on the presence on football match. Therefore, respondents were divided into three groups of supporters according to their own declarations of involvement in club matches. The first group are occasional fans who rarely go to matches and rarely engage in doping, match setting and buying club gadgets. From among respondents, 363 people declared such behaviour.

The second group of respondents is a group of people who treat matches as an entertainment, using the match as an opportunity to meet friends, spend free time, without much involvement in the result or cheering. Such behaviour was declared by 194 people.

The third group is a group of fans which includes people involved in support, who are interested in sports results and club activities. It was the largest group represented by 555 people in the study.

All these groups were compared in terms of their own sense of security at the stadium. The combination of these groups and questions about the sense of security during the match was made in Table 1.

Table 1

Empirical numbers of the comparison of fans' categories and their sense of security

\begin{tabular}{|c|c|c|c|c|c|}
\hline $\begin{array}{c}\text { Sense of safety } \\
\text { at the match } \\
\text { Categories of } \\
\text { supporters }\end{array}$ & $\begin{array}{c}\text { Yes, } \\
\text { completely }\end{array}$ & feelrathersafe & $\begin{array}{c}\text { I do not } \\
\text { I keep all } \\
\text { precautions } \\
\text { every time } \\
\text { I prefer } \\
\text { to watch } \\
\text { matches } \\
\text { at home }\end{array}$ & Together \\
\hline $\begin{array}{c}\text { Occasional } \\
\text { supporter }\end{array}$ & 64 & 98 & 18 & 183 & 363 \\
\hline $\begin{array}{c}\text { People who treat } \\
\text { matches as an } \\
\text { entertainment }\end{array}$ & 68 & 75 & 45 & 6 & 194 \\
\hline Fan & 210 & 263 & 48 & 34 & $\mathbf{5 5 5}$ \\
\hline Together: & $\mathbf{3 4 2}$ & $\mathbf{4 3 6}$ & $\mathbf{2 2 2}$ & $\mathbf{2 2 3}$ & $\mathbf{1 1 1 2}$ \\
\hline
\end{tabular}

Source: Own study 
Table 1 can be used as a starting point to determine if there is a sense of security to participate as a viewer in a football match. The chi-square test is the test that allows you to put and verify this hypothesis. For individual table cells, the theoretical number is determined according to the formula:

$$
\widehat{\mathbf{n}}_{\mathbf{i j}}=\frac{\mathbf{n}_{\mathbf{i} \cdot \mathbf{n} \cdot \mathbf{j}}}{\mathbf{n}}
$$

By calculating the theoretical quantities according to formula (1), we obtain Table 2.

Table 2

Theoretical numbers of comparing the categories of supporters and their sense of security

\begin{tabular}{|c|c|c|c|c|c|}
\hline $\begin{array}{c}\text { Sense of safety } \\
\text { at the match } \\
\text { Categories of } \\
\text { supporters }\end{array}$ & $\begin{array}{c}\text { Yes, } \\
\text { completely }\end{array}$ & $\begin{array}{c}\text { I } \\
\text { feelrathersafe }\end{array}$ & $\begin{array}{c}\text { I keep all } \\
\text { precautions } \\
\text { every time }\end{array}$ & $\begin{array}{c}\text { I do not } \\
\text { feel safe, I } \\
\text { prefer to } \\
\text { watch } \\
\text { matches } \\
\text { at home }\end{array}$ & Together \\
\hline $\begin{array}{c}\text { Occasional } \\
\text { supporter }\end{array}$ & 112 & 142 & 36 & 73 & 363 \\
\hline $\begin{array}{c}\text { People who treat } \\
\text { matches as an } \\
\text { entertainment }\end{array}$ & 60 & 76 & 19 & 39 & 194 \\
\hline Fan & 171 & 218 & 55 & 111 & $\mathbf{5 5 5}$ \\
\hline Together: & $\mathbf{3 4 2}$ & $\mathbf{4 3 6}$ & $\mathbf{2 2 2}$ & $\mathbf{2 2 3}$ & $\mathbf{1 1 1 2}$ \\
\hline
\end{tabular}

Source: Ownstudy

The further research procedure involves the comparison of the empirical size with the theoretical number according to the formula (2) and the determination of the empirical value for the chi-square factor:

$$
\chi^{2}=\sum \frac{\left(\mathbf{n}_{\mathrm{ij}}-\hat{\mathbf{n}}_{\mathrm{ij}}\right)^{2}}{\hat{\mathbf{n}}_{\mathrm{ij}}}
$$

After converting the appropriate cells, the value of the empirical chi-square is 346.29. After comparing this number with the data from the chi-square distribution tables, it turns out that regardless of the assumed confidence interval, the zero hypothesis about the independence of features such as feeling of safety and presence at club football matches should be rejected.

\section{DISCUSSION AND CONCLUSION}

The purpose of the article was to determine the relationship between the sense of safety of sports club fans and active participation in a sporting event. The research concerned football club supporters, because here the problem is the largest. After conducting research and statistical calculations, it turned out that security is one of those values that directly determine the use of the service - participation in the event. The main hypothesis is that a sporting event allows to extend a marketing offer to new segments, enrich the expanded sports product, set new pricing strategies and use the promotion only when the viewer has a high sense of security. 
The first part of the article indicated that football sports clubs are obliged to observe the safety rules at stadiums. The act on the safety of mass events, to which clubs are strictly required, serves this purpose. According to the study, despite the obligations imposed on clubs, the role of the police and compliance with safety standards, some of the supporters of a given club do not come to the stadium (this applies mainly to football clubs) because they do not feel safe there. This is due to sports and non-sport emotions as well as groups posing a potential threat.

In this context, the tasks of the sports club, in addition to compliance with the Act, are:

- emphasizing the importance of safety at the stadium and outside it,

- eliminating unwanted behaviours which are a threat to the safety of fans in the club,

- resisting any behaviour that constitutes a real or potential threat both inside and outside the stadium,

- promoting tolerance towards other clubs and sport as a form of entertainment,

- promoting community activities, connecting all supporters, not just groups.

The football club's tasks thus included should be part of the sport club's broad marketing policy. Through marketing tools, a club (in this case a football club) should influence the supporters groups to encourage them to come to the stadium. Eliminating the feeling of danger, it should attract those football fans who were assigned to groups of occasional fans.

An example of the optimal use of these tools is: consistent condemnation of acts of vandalism at the stadium, separation of groups posing a threat to other fans at the stadium and outside, cutting off from criminal activities of their own fans' groups, consistent and unambiguous communication policy towards antisocial attitudes related to the club. After the research, it should also be stated that safety is a very important factor in the fact that the sports club can expand its marketing offer. This applies to the expansion of a comprehensive sports product, pricing policy or distribution. The new offer is targeted at segments that appear with increasing sense of security. These segments include, for example, families with children who can be offered family sectors, play areas for children, additional attractions, competitions. In turn, these additional elements of the overall sports product affect the satisfaction and, as a result, the desire to come back to the stadium, and as a result loyalty.

In this approach, it is the sense of security from the point of view of the customer that determines the use of the sports service, as well as this satisfaction and that loyalty.

It is also worth repeating that while clubs have to do everything to meet the requirements of the Act, what allows to raise the sense of security among occasional fans and motivate them to come to the stadium is a skilful and balanced marketing policy of sports clubs. Part of this policy is to fulfil the tasks related to the sense of security of all fans in a thoughtful and consistent manner.

\section{REFERENCES}

Borys D., Donaldson A., Finch C. F., 2013. Understanding safety management system applicability in community sport, Safety Science, Volume 60.

Kaviya S., Praditsathaporn S., Yuparin P. P., 2010. Sport safety improvement using security camera without audience privacy violation, Procedia - Social and Behavioral Sciences Volume 2, Issue 1. 
Lee J., Fereira M., 2012. A role of team and organizational identification in the success of cause-related sport marketing, Sport Management Review, Volume 16, Issue 2.

Jędrzejas N., 2017. Security management of mass events, World Scentific News, http://www.worldscientificnews.com/wp-content/uploads/2017/01/WSN-72-2017347-352.pdf, 2.

Kamiński A., Majchrzak B., 2012. Bezpieczeństwo imprez masowychOdpowiedzialność organizatora. Policja 997, 24-25.

Kulińska E., Rut J., Pytel A., 2014. Logistyka zapewnienia bezpieczeństwa imprezy masowej, Logistyka, Nr 4, 665.

Łukawski R.K., 2016. Bezpieczeństwo imprez masowych, Przegląd Sił Zbrojnych, Nr $5,117$.

Parszowski S., Kruczyński A., 2015. Imprezy masowe, organizacja, bezpieczeństwo, dobre praktyki, Difin SA, Warszawa, 15.

Popławski A., 2016. Bezpieczeństwo imprez masowych - wybrane zagadnienia, Colloquium wydziału Nauk Humanistycznych i Społecznych AMW, Nr 3(23) Gdynia, s. 144.

Raineri A., 2016. Contemporary planning approaches for crowd safety at mass gatherings, Conference: Safe Cities Conference, Melbourne, Australia, 11.

Suski P., 2010. Zgromadzenia i imprezy masowe, LexisNexis, Warszawa, 317.

Szymonik A., 2011. Logistics mass events, Publishing Difin, 12.

Wojciechowski R., 2013. Bezpieczeństwo uczestników imprez masowych, Zeszyty Naukowe Uniwersytetu Przyrodniczo- w Siedlcach, Nr 97, 179. 